\title{
A MORTE COMO VENENO, A NARRATIVA COMO ANTÍDOTO
}

Cibele Lopresti Costa ${ }^{1}$

RESUMO: Este artigo analisa a representação da morte em Antídoto, de José Luís Peixoto, considerando as diferentes referências inscritas no livro. O texto e os paratextos apontam para a reflexão sobre tradição e ruptura, já que se referem à música heary metal e também à visão poética e sublime do assunto.

PALAVRAS-CHAVE: morte, sublime, tradição.

ABSTRACT: This article examines the representation of death in Antidote, by José Luis Peixoto, considering the different references listed in the book. The text and paratexts point for reflection on tradition and rupture, as it refers to heavy metal music and also the sublime and poetic vision of the subject.

KEY-WO RDS: death, sublime, tradition.

Antídoto, de José Luís Peixoto, apresenta-se como um livro conciso, breve e atravessado por outra linguagem, a da música radical do heavy metal. Essa informação inicial certamente é provocativa, já que temos um autor português atualizando paradigmas e instigando nossa curiosidade. Há que se saber de que trata esse jovem autor e como ele trata, afinal, a literatura portuguesa.

A contracapa da narrativa parece instigar nossa curiosidade ao revelar que o livro "é uma novela de contos inspirada no universo musical do disco The Antidote" do grupo heavy metal português Moonspell. O primeiro estranhamento está na autodenominação: novela de contos.

Como se configura uma novela de contos? Nesse caso, constitui-se na sequência de pequenos textos narrativos que, inicialmente, parecem independentes. Entretanto, o conjunto deles revelam pequenos quadros dramáticos que, relacionados, contam uma história.

A contracapa lança ainda outra frase instigante sobre a relação entre livro e música: “Dois antídotos para um mesmo veneno". O gênero musical citado tem raízes no rock e, por isso, traz em si a transgressão a qualquer tradição. Sabe-se, ainda, que o gênero tem sonoridade acentuadamente eletrônica, com distorções vibrantes e expressão teatralizada. O tema gótico é recorrente, por isso o preto parece ser a cor predileta dos adeptos dessa poética, o que fica bem explicitado nos figurinos e iluminação de palco nos momentos dos shows.

O funéreo permeia essa expressão, transportando-nos ao submundo da cultura, à morte como limbo. Essa concepção limitou nosso poder imaginativo frente ao tema,

\footnotetext{
${ }^{1}$ Doutoranda em Literatura Portuguesa na Universidade de São Paulo - USP
} 
devido à maneira mórbida como o trata. Tivemos a impressão de estar lado a lado dos que sofrem, dos que mantêm a percepção da dor e da morbidez, desconsiderando a transcendência e deixando-nos fixados na impossibilidade do ser. A primeira impressão sugeriu-nos a dor da morte como um sofrimento inexorável, coibindo qualquer possibilidade de representação estética. "O sofrimento efetivo não permite (...) nenhum juízo estético, pois suspende a liberdade do espírito.” (SCHILLER, 2011, p. 48).

Assim entramos no livro, por essa porta, ao rés-do-chão. Entretanto, descobrimos algo inusitado, já que o texto literário sugere exercício de subjetividade em expansão, gesto literário de profundidade íntima, caminho para a interioridade. Sua leitura provoca sentidos, na medida em que espelha ou tenciona diferentes pontos de vista sobre ausências e ressignifica a percepção sobre a finitude.

O fio narrativo que alinhava os pequenos textos desenha impressões sobre morte e vida, fissuras e/ou deslocamentos que ocorrem nesse intervalo. Por meio de imagens, temse a trajetória de duas pessoas - do nascer ao morrer - que vivem a irrealização do amor. Há duas personagens principais, um homem e uma mulher, que convivem desde cedo com a percepção da impermanência e incomunicabilidade das relações, ele perde o pai muito cedo, ela tem anomalia física que a impede de se entregar ao amor. Nada é dito entre eles e tudo se apresenta como motivo para a irrealização, pois parecem fadados à tristeza. A composição da narrativa se faz pela alternância das vozes desses personagens em concomitância a uma terceira voz na primeira pessoa do plural que parece tudo saber, tudo antever. É o nós que nos insere na narrativa. O livro compõe-se pelas imagens de ser, de mim e de si(s).

Para constituir essas imagens, há alternância de foco narrativo: ora em primeira pessoa do plural, ora do singular e quando é uma única voz, pode ser a do homem ou da mulher. Mas todos convergem para temas similares - a finitude e a impossibilidade -, fazendo deles um capítulo. O tom fatalista do início antecipa o tema central da morte:

Continua teu caminho. Segue por essa linha da nossa mão. Nós sabemos onde termina esse túnel em que caminhas. Continua a caminhar. Nós esperamos por ti. Sorrimos a ver-te. Depois das nuvens, somos o medo. Debaixo da pele, somos o medo. (PEIXOTO, 2003, p.10)

$\mathrm{Na}$ passagem acima, nota-se que a voz plural sugere que não há saída para o humano, pois a morte é o fim do túnel e o medo esbarra em qualquer presença. O som das vozes, nesse caso, parece ecoar as moiras gregas, cujo canto anuncia o irremediável destino. 
A lembrança delas vem ao encontro de nossa impressão de que podemos ler nas entrelinhas dessa escritura elementos da tra dição.

Entretanto, há a alternância do foco narrativo, como verificaremos a seguir. Essa estratégia promove simultaneidade, reflexos discursivos e interpolação de vozes. Por um lado, esse jogo reforça a impressão de incompletude e insignificância dos desejos, pequenez do sujeito frente à força que parece sobrepor-se às vontades; mas por outro, apresenta as impressões de vozes distintas sobre o tema que resistem à fatalidade.

O capítulo que segue o trecho acima destacado focaliza a experiência da personagem masculina frente à morte:

Os dedos da minha mãe seguravam os meus dedos. Pelas nossas mãos passava alguma coisa invisível, calor, luz, que era muito maior que nós. Eu olhava para o céu porque esse era o tamanho daquilo que existia entre mim e a minha mãe. E havia ainda o som da porta de casa a fecharse. Na claridade daquela manhã, parecia-me que, como a porta da casa, alguma coisa se fechava para sempre. Eu e minha mãe avançávamos pelas ruas da vila de mão dada. (idem, p. 11)

O fragmento refere-se ao momento da partida do pai, o capítulo mimetiza a perda irreparável no contraste entre a luz do espaço aberto e a possível sombra da porta a fecharse, contextualiza o momento em que a personagem, ainda criança, reconhece a impotência frente à morte na imagem da porta cerrada eternamente. Assim como em Morreste-me (2009), a primeira publicação do autor, o tema da morte se faz presente e o processo do luto parece presencificar-se na estratégia das recorrências e repetições. Entretanto, os dedos seguros da mãe sugerem que há vínculos possíveis, um fio resistente que o mantém preso à vida e o título começa a fazer algum sentido. O antídoto conjectura-se como possibilidade nos dedos entrelaçados?

Vê-se que a concretude do fim não anula a firmeza da ternura que ainda há. Embora sejamos avisados pelo narrador em terceira pessoa sobre a impotência e ignorância frente à morte, há que se considerar o lirismo dos afetos entrelaçados nas mãos dadas entre mãe e filho e as retomadas que materializam a poeticidade do texto:

Era o silêncio. A terra esperava passos. O sol esperava olhares para iluminar. O tempo, julho, existia na distância entre os objetos suspensos. Nós assistíamos à espera do mundo. A terra sabia. $\mathrm{O}$ sol sabia. $\mathrm{O}$ tempo sabia. Nós sabíamos. Os homens não sabiam. Ele e ela não sabiam. (ibidem, p. 17) 
A estratégia da alternância de pontos de vista promove, ainda, imagens paradoxais. No primeiro texto, tem-se a primeira pessoa do plural; no segundo, a primeira do singular, a VOZ do homem contando suas impressões sobre a morte do pai. Em seguida, retorna a primeira pessoa do plural e a sequência prossegue nessa toada até que se apresenta outra vOz em primeira pessoa, a de uma mulher cujas lembranças são ternas:

Eu era demasiado pequena para entender. Em noites como esta, a minha mãe cantava-me canções. A sua voz estendia-se sobre o meu rosto deitado na almofada. Eu sentia a suavidade da voz da minha mãe. As suas palavras, como a sua voz, eram a paz, e tudo era essas palavras e essa voz. (ibidem, p. 44)

O conjunto de vozes parece expressar incongruências, pois o plural generaliza impressões sobre os acontecimentos ou sensações, sugerindo universalidade, e as diferentes vozes em primeira pessoa particularizam as sensações, revelando contradições. A composição desse conjunto se assemelha a um retrato feito à base de colagens, retratos de momentos, fragmentos de memória que compõem o arremedo da morte.

Tem-se, no plano da universalidade, a visão fúnebre dos fatos, como se a fatalidade fosse marca do viver, aproximando tudo a essa experiência. Nos planos particulares, há o registro das vozes que procuram algum sentido à vida, um antídoto ao mal que é a morte. O que se tem em jogo é a busca pela ressignificação dela, já que o desfecho realmente é o fim da vida das personagens.

Esse jogo problematiza a morte, sugerindo a ela dois aspectos: primeiramente rebaixa o humano à insignificância, à impotência, e a apresenta como mau destino. Em seguida, representa-a como possibilidade de transcendência e libertação, na medida em que aproxima o ciclo do viver ao da natureza e sugerindo a morte como boa fortuna. É relevante observar como a voz masculina refere-se à trajetória:

Diante de mim, um manto de pontos de luz que se acendem e apagam. A sua vida é breve. A minha vida é breve. São pontos de luz que abrem caminhos para que avance. As minhas botas pousam entre esses pontos de luz a nascerem, a viverem durante um instante e a morrerem para sempre. (...) A repousar no topo do muro, a escorrer como uma avalanche suspensa, há plantas, folhas, ramos de árvores: braços verdes que pararam no momento em que 
lançavam para agarrar alguém que, como eu, caminhava no passeio. (ibidem: p. 55)

Vejamos um pouco mais como se realiza esse jogo. No primeiro texto, o foco narrativo em terceira pessoa apresenta a verdade já sabida por aqueles que já viveram o necessário. Para explicá-la, o enunciado faz uso do termo comparativo 'como'.

As raízes agarram-se ao coração e nós cobrimos cada dedo fino dessas raízes que se fecham e apertam e esmagam essa pedra de fogo. Como sangue, somos lágrimas. Como sangue, existimos dentro de gestos. As palavras são, tantas vezes, feitas daquilo que significamos. E somos o vento, os caminhos do vento sobre os rostos. O vento dentro da escuridão como o único objecto que pode ser tocado. Debaixo da pele, envolvemos as memórias, as ideias, a esperança e o desencanto. (ibidem, p. 7)

Nota-se que o trecho confirma alguns traços constantes na poética do autor. O primeiro a ser destacado é o recurso da comparação. A prosa reverbera as impressões do emissor e as comparações aproximam sentidos, apontam semelhanças, deixando um espaço singular entre signos e sentido, diferente daquele deixado pela metáfora. Nessa, a relação entre as duas instâncias parece mais próxima, simétrica e coincidente enquanto que na comparação há que se considerar o esforço retórico da explicação. A recorrência do 'como' em quase todos os textos de Antídoto confere ao conjunto de vozes o esforço do pensamento, a saturação do pensar e intensifica o tom melancólico do livro.

Outro traço constante ao longo da narrativa é a presença dos elementos da natureza. No fragmento citado, a escolha lexical localiza o cenário no ambiente rural: 'raízes', 'pedra', 'fogo', 'vento'. A esses termos somam-se 'terreiro', 'lua', 'céu', 'deserto', 'nuvens', 'terra'. Essa impressão se confirma no capítulo intitulado Sul. Nele, as impressões sobre o lugar revela que o ambiente rural impregna o texto, amalgamando sensações, o que pode ser verificado em "Essa luz misturava-se com a sombra da casa. Entrava pela janela e não havia uma linha onde a sua claridade acabasse. No chão, havia a luz a escurecer e, depois, essa luz escurecida era a sombra." (ibidem, p. 23)

Nesse aspecto, o texto ecoa a tradição do idílio, na medida em que parece fazer uso de analogias entre o ser e o ambiente rural para a criação literária.

Tomamos aqui o termo citado como sinônimo de "visão utópica de uma existência junto à natureza", segundo Massaud Moisés, em seu Dicionário de termos literários. Tem-se a impressão de que, no livro de José Luís Peixoto, essa utopia se manifesta na associação 
entre espaço e tempo, na medida em que são apresentadas essas duas instâncias ligadas à imagem da metamorfose dos seres e signos do mundo. As transformações sacralizam-se nos movimentos do nascer e do morrer, o que sublima as experiências de viver e morrer:

Os dedos da minha mãe eram grossos no momento em que, com ambas as mãos, me levantou no ar, sobre sua cabeça, na direção da lua e disse: Ó lua, ó luar,/ eu fi-lo nascer/ ajuda-mo tu a criar. Eu era pequeno e branco. Nos olhos da minha mãe viam-se os seus braços erguidos, via-se o meu corpo dentro do círculo branco da lua. (ibidem, p. 57)

Nesse sentido, vê-se que em Antídoto reverbera a tradição literária nos espaços em que se pode ler o idilio clássico, resgate da cultura portuguesa na composição do tempo inaugural e pleno de felicidade, e exercício estético na formulação de uma prosa literária fragmentada e poética. O conjunto desses aspectos confere certa amplitude ao texto, promovendo qualidade literária e deslocando o tema central da morte a um grau de reflexão mais elevado. Os sons estridentes do heavy metal parecem apagar-se em favor da sonoridade poética dessa prosa.

A narrativa amalgama a natureza à experiência subjetiva do existir no tempo-espaço para sugerir possíveis (re)significados à morte. Há uma geografia das emoções na coexistência de passado e presente, memória e esquecimento, luz e sombra no ambiente rural, aos quais são atribuídos valores intrínsecos ao humano. Nesse caso, o antídoto para a impotência frente à morte parece ser a linguagem poética que pode perpetuar lembranças e aniquilar o esquecimento. Voltemos aos dedos entrelaçados.

O último capítulo, por meio de linguagem poética rarefeita, sugere o suicídio das personagens. $\mathrm{O}$ narrador indicia que as personagens deitam-se sobre os lençóis brancos da cama e, de mãos dadas, o "cano da caçaderia" dá fim à vida das personagens. A representação da partida deles sugere a transcendência do amor como antídoto contra $O$ fim e contra as impossibilidades: "e passaram juntos pela última vez em todos os lugares do mundo e, juntos, prepararam-se para adormecer eternamente" (p. 87). Dessa forma, as mãos entrelaçadas configuram a resistência ao fim e ao esquecimento.

A leitura dessa narrativa fragmentada promove uma visão singular sobre a finitude, já que a natureza, a passagem do tempo e o retorno às origens parecem caminho natural entre vida e morte. O tom idilico transforma-se em elegíaco e somos levados a pensar nas ações do bem viver e do bem morrer, elevando o tom da reflexão e lançando-nos a patamares mais elevados, sublimes sobre a condição humana. 
Entretanto, a presença desses traços não é exclusiva a esse texto, por isso pode-se dizer que são elementos estruturantes da obra do autor. Voltemos ao capítulo Sul. Lá, há a personagem chamada somente por "mulher do monte". Essa figura aparece também no conto $A$ idade das mãos, do livro Cal (2007). Nos dois textos, a imagem da mulher vincula-se à representação da passagem do tempo, do espaço rural, da memória dos afetos e também da morte. O fragmento a seguir, embora seja de Antídoto, caberia perfeitamente no conto citado:

No monte, a sua solidão espalhada de encontro às planícies. Ninguém sabe qual foi ontem a cor das sombras e da claridade no monte, porque ontem essa mulher deu comida aos cães e fez-lhes festas e caminhou para a casa onde guardava enxadas e sementes. Ontem, a mulher do monte levou por três vezes o veneno das batatas aos lábios. O veneno atravessou-lhe a garganta, um caminho de fogo. (ibidem, p. 24)

Ou seja, os narradores projetam impressões do espaço-tempo da natureza, e a relação intrínseca entre essas categorias define a forma de narrar desse autor. A luz do sol do sul de Portugal, as casas brancas pintadas à cal e a rotina dos velhos e velhas com seus animais de estimação são temas frequentes e parecem agir conforme a natureza desse lugar.

Em outra passagem, a voz da mulher reverbera as vozes do narrador ou do pai do livro Morreste-me:

Imaginava o sol que cobria cada instante desses dias. Em cada árvore, encontrava horas rasgadas do tempo. Em cada erva nova a nascer. Estava muito tempo a pensar em tudo. Os pensamentos dentro dela, eram como lugares a envolvê-la. A mulher do monte pensava no sol e aquele sol que pensava era o sol que a iluminava e aquecia. (PEIXOTO, 2009, p. 25)

O cruzamento dessas imagens de escrita colabora para o desenho que pretendemos fazer da poética de José Luís Peixoto. A representação da passagem do tempo está intimamente ligada ao estado da natureza que, embora pareça ser traduzida em estações do ano, apontam para o campo das sensações. Não importa quanto tempo é transcorrido ou a que estação do ano a escritura se refere, importa sim o quanto se tem na lembrança o tempo experenciado. Especialmente em Antídoto, a escritura de José Luís Peixoto potencializa o aspecto imaginativo e ficcional da escrita, pois favorece o caráter poético - e livre - da linguagem. 
E, ao fechar o livro, voltamos novamente à contracapa. O que se anunciava inspirado na cultura $p$ p , transcende-se à reflexão filosófica sobre a morte e enaltece a força das palavras e, por que não, do amor.

\section{Bibliografia}

ARISTÓteles, HORÁCIO, LONGINO. A Poética Clássica. São Paulo: Cultrix, 1997.

AUERBACH, Erich, Ensaios de Literatura Ocidental. São Paulo: Livraria Duas Cidades, Editora 34, 2007.

MOISÉS, Massaud. Dicionário de termos literários. São Paulo: Cultrix, 12a ed. 2004.

PEIXOTO, José Luís. Morreste-me. Lisboa: Quetzal, 8ª ed., 2009. Cal. Lisboa: Bertrand, 2008. Antídoto. Lisboa: Temas e Debates, 2003.

SANTAELLA, Lúcia. Estética - de Platão a Peirce. São Paulo: Experimento, 2000.

SCHILLER, Friedrich. Do sublime ao trágico. Tradução de Pedro Süssekind. Belo Horizonte: Autêntica Editora, 2011.

Artigo recebido em 19 de Março de 2012 e aprovado em 17 de Maio de 2012 